\title{
Mutual Gains from Hostile Confrontations: Land Boards, Their Clients and 'Self-allocation' in Botswana
}

\author{
Ato Kwamena Onoma*
}

\begin{abstract}
This article argues that hostile confrontations between state and societal actors pursuing divergent goals can sometimes end up empowering both. In Botswana, successful efforts by less powerful clients to reclaim the power to allocate land from land boards through various stratagems ended up also strengthening the land boards and also the state. By tricking land boards into legitimizing plots on which they had squatted, clients brought their land interests to the awareness of the land board and contributed to bettering land board records. The better records enable land boards to allocate land and resolve disputes in more informed ways. Better records also provide state officials with valuable information that various state agencies can use to tax, police, plan and implement various social projects better. In presenting this argument, the article contributes to the state-in-society discourse by showing that we need not limit the possibility of positive sum gains to situations where state and societal actors collaborate to achieve mutual goals.
\end{abstract}

\section{Résumé}

Cet article soutient que les confrontations hostiles entre l'État et les acteurs de la société poursuivant des objectifs divergents peuvent parfois finir par rendre ces deux parties plus fortes. Au Botswana, les efforts réussis de clients moins puissants pour reconquérir le pouvoir d'attribution des terres détenu par les groupements de propriétaires terriens à travers divers stratagèmes ont également fini par renforcer ces derniers ainsi que l'État. En bernant les groupements de propriétaires terriens à la légitimation de parcelles sur lesquelles ils squattaient, des clients a amené ces derniers à prendre conscience de leurs intérêts terriens et a contribué à l'amélioration de leurs acquis. Cette amélioration des acquis

* Department of Political Science, Yale University. E-mail: ato.onoma@yale.edu; kwamena_onoma@yahoo.com. 
permet groupements de propriétaires terriens d'attribuer les terres et de résoudre les différends de manière plus informée. En outre, elle donne aux autorités de l’État de précieuses informations que les différents organismes étatiques peuvent utiliser pour mieux taxer, suivre, planifier et mettre en œuvre divers projets sociaux. Dans la présentation de cet argument, cet article contribue ainsi à l'approche État dans la société en montrant qu'il ne faut pas limiter la possibilité d'augmentation des acquis positifs dans des situations où l'État et les acteurs de la société collaborent pour atteindre des objectifs communs.

\section{Introduction}

In February 2004, I attended an allocation exercise where a state-created subordinate land board in Botswana convened at a village to allocate land, settle land disputes, document existing land interests, and authenticate land transfers. Many clients went to the board seeking land documents claiming, among other things, that their original certificates of customary land grant had been destroyed by floods or had been eaten by insects or cattle. Land board members suspected many clients of committing the offence of selfallocation, in which clients had illegally squatted on land and tried to fool the board into legitimizing their activities by claiming lost certificates. Land board members conceded that since the land board lacked good records of past allocations it was difficult to prove the (in)validity of claims, and reluctantly agreed to issue 'new' certificates.

These stratagems by villagers are examples of the 'everyday forms of resistance' (Scott 1985:xvi) that the peasantry deploys to work state imposed systems 'to its advantage - or rather to its minimum disadvantage' (Hobsbawm 1973:13). Scholars recognize the potentially devastating effects of these acts on grand state designs (Scott 1990:188-95; Migdal 1988: 33; Herbst 2000:18; Hyden 1983:194). In the literature on state-society relations hostile confrontations between state administrators and social actors are presented as zero-sum games in which the triumph of one party comes at the expense of the other (Migdal 1988:33; Hyden 1983:194). This view even extends to the state-in-society perspective, which explicitly considers mutually empowering state-society interactions (Kohli and Shue 1994:323). In this literature, occasions of mutual empowerment are limited to those nonantagonistic interactions when state and societal actors set out to achieve mutual gains based on convergent goals (Kohli and Shue 1994:321; Migdal 1994:24-5; Evans 1995:49). Migdal, one of the editors of the pioneering volume on the state-in-society approach, thus notes that in cases where there is a 'struggle for agency, for the ultimate autonomy to take initiatives and to make decisions in given realms ... the struggle is one marked not by mutual empowerment but by mutually exclusive goals’ (Migdal 1994:24). 
This paper pushes the state-in-society debate further by arguing that we need not limit the possibility of positive sum gains to situations where state and societal actors collaborate to achieve mutual goals. To do this I engage literatures on property rights, the uses of knowledge and information systems and state-society relations. I argue that hostile confrontations between state and societal actors pursuing divergent goals can sometimes end up empowering both. In contemporary Botswana, successful efforts by peasants to reappropriate the power to allocate land from land boards and their central state bosses end up also strengthening land boards and the state. Land board officials and state authorities detest and try to stop these deceptive devices, mostly in vain. But by fooling land boards into documenting their self-allocated plots and thus bringing these land interests to the attention of the land board, clients contribute to bettering land board records and the state's land information system. The better records enhances land boards' ability to engage in informed dispute resolution and land allocation and limits the extent to which clients can rob them of land allocation powers. Separately, better records also provide other state agencies with information that can use to tax, police, and plan and implement social projects (Interview 9).

Primary data for this research was gathered during five months of field research in Botswana. I conducted in-depth semi-structured interviews, many informal discussions, and attended land board and land tribunal meetings in Central, Kweneng, Kgatleng, Northeast and Gaborone districts. During one of my trips, I was privileged to participate in the operations of the Mahalapye subordinate land board. My experiences of the activities of this subordinate land board deeply informed my understanding of the micro-politics of land transactions. I have omitted the names of informants to keep their identities secret.

In the section that immediately follows, I discuss and outline the centralizing and domineering designs of states with particular emphasis on the Batswana state and its efforts at reorganizing land administration. Next, I discuss various modes of resistance deployed by clients to take back powers to allocate land from the land boards. The following section examines how successful resistance by clients ends up strengthening land boards and the state. In the conclusion, I draw on this analysis to suggest a broader line of research project on the impact of successful resistance by social actors on states.

\section{Confrontations as Zero-sum Games: Land Boards and Self- allocation}

The creation of the modern-nation state and its efforts at administering and transforming society has meant a centralization and deployment of powers formerly held by various local chieftains to tax, police, prosecute wars, and transform society in very intrusive and coercive ways (Anderson 1979; Spruyt 
1994:153; Tilly 1990:63; Migdal 1994:11-13; Weber 1946:78; Evans 1995:5). The creation of colonial states in Africa followed a similar logic even if only in aspiration (Herbst 2000:17-31; Bratton 1994:233). Traditional leaders that previously enjoyed vast powers became at least de jure subordinates to colonial and postcolonial state leaders (Arhin 1985; Proctor 1968).

In Africa, Botswana has to be considered as one of the states that have achieved considerable success in transforming its society (Samatar 1999). At independence in 1966, it was one of the more hopeless new states (Picard 1985:19), seemingly lacking significant minerals and fertile soils suitable for export agriculture. The discovery of diamond reserves after independence in 1966 gave the state huge resources. The Botswana Democratic Party (BDP), which has ruled the country since independence, has used these resources to transform the country into one of the most prosperous on the continent. The BDP has sought with considerable success to tightly control the mining and marketing of diamonds, reform and boost the cattle sector, provide various services for its citizens, and fund a burgeoning education sector (Samatar 1999).

The land sector is one area that has felt the heavy hand of the state. The first National Development Plan, released in 1968, stated with regard to land that 'The need for reform is recognized and detailed study of the possible changes which might be introduced is being made.' The goals were to render land a 'fully negotiable asset' and give 'progressive farmers' greater security 'than that available under customary law' (Botswana 1968a:10). The Tribal Land Act passed in 1968 has been the main instrument employed by the state to reorganize the administration of tribal lands, which constituted 70 per cent of all lands in Botswana by 2004 (Kalabamu and Morolong 2004:61-3). Tribal/customary lands in Botswana are lands whose ownership is vested in whole communities. Formerly, chiefs and since 1968, land boards as custodians, administer these lands on behalf of communities. Various group members can acquire exclusive user rights for various lengths of time in tribal land. Despite the continuing use of the word 'tribal', Section 10 of the Tribal Land (Amendment) Act of 1993 made these lands in principle the property of all citizens of Botswana and the land boards stewards of all Batswana, even if their perception as agents of various 'tribes' still continues in the popular imagination (Nyamnjoh 2007: 311; Werbner 2004:109:30).

The Tribal Land Act was a very disruptive instrument even though it sought to maintain the customary land tenure to which customary lands were subject. Section 3 of the Act provided for the creation of land boards across the country, while Section 13 transferred all powers formerly held by traditional chiefs in the administration and management of land to land boards. The staff and members of these land boards were subject to appointment 
and/or dismissal by the Minister for Lands and Housing. The membership of land boards has been reformed over time (Kalabamu and Morolong 2004:502). By 2004, board members were elected by villagers at the kgotla (in Setswana, kgotla is a discursive and deliberative body made up of citizens of an area and presided over by the chief; it also refers to the physical structure where these meetings take place [Thapelo 1997:2; Molosiwa 1999:51]) from a pool selected by a committee headed by the district commissioner (Interview 11), ensuring that board members remained 'agents of the central government' (Kalabamu and Morolong 2004:52) As Kalabamu and Morolong (2004:48-9) note, by creating the land boards, 'the government had enable[d] itself to define and enforce rules on access, use and disposal of tribal land'. Main Land Boards were established in 1970 and subordinate land boards in 1973 (Mathuba n.d.:4; Wynne 1989:1). By 2004 there were 12 main land boards and 39 subordinate land boards across the country (Kalabamu and Morolong 2004:51).

Over time, the offence of self-allocation has become a central preoccupation of land board members (Werbner 1980:135-45). In 2004, the punishment for self-allocation was the hefty sum of 10,000 pula (around US\$3,000), a year in jail and possible demolition of the properties and seizure of the land (Interview 32). The power to allocate land presents board members with a powerful instrument, which they can potentially use to achieve various ends including aiding state development plans and gaining influence for political careers (Comaroff 1980:108; Werbner 1980:135-45). Board members need to reinforce their monopoly over land allocation so they can deploy that power to their chosen ends. If everyone can allocate land, board members will have no power to deploy. The unauthorized allocation of land by any other person fractionally dissipates their power hence their distaste for the offence of self-allocation.

In the next section I show that threats of a year in jail and a 10,000 pula fine have not dissuaded many from successfully prizing significant land allocation power from the land boards through the practice of self-allocation. I then discuss how these successful efforts at resistance paradoxically strengthen land boards and the state.

\section{Hostile, But Wily Resistance to Land Board Allocation Powers}

More powerful actors have often overtly resisted land boards in Botswana (Werbner 2004:111-12; Nyamnjoh 2007:308-9). But my observation of interactions between state land agents and less powerful social actors revealed that there have been continuous and significantly successful efforts by these actors to reappropriate the power to allocate land from land boards. Scott has noted that because peasants are dispersed over large areas, are often not 
formally organized, and lack means of coercion comparable to the dominant, 'they typically avoid any direct, symbolic confrontation with authority' (Scott 1985:xvi). Peasants often resort to weapons such as the manipulation of knowledge and ignorance that reinforce their hands in these struggles (Scott 1990:133). Acts of resistance by less powerful Batswana have taken the form of continuous low-scale resistance, employing knowledge instead of coercive force as a weapon of choice. Their strategy has been to manipulate the new system to take land allocation powers from land boards (Wynne 1989:387-89) instead of openly denying the monopoly of land boards over the power to allocate land.

Knowledge and ignorance have become key weapons in the struggle between land boards and their less powerful clients over the ability to allocate land (Wynne 1989:387-9). Long ago Hayek distinguished between the 'scientific knowledge' of central state officials and 'knowledge of the particular circumstances of time and place' of locals (Hayek 1945:521). He emphasized the importance of knowledge of local circumstances to processes of governance. The effort to transform society by state officials requires bureaucrats to integrate knowledge of local realities into general scientific knowledge that will direct the exercise of state power (Hayek 1945:521; Scott 1998:313). Central state officials are often aware of the importance of such knowledge (Scott 1998:23). Where officials lack sufficient knowledge of local circumstances, they will be unable to direct the exercise of state power in ways that will bring about the targeted transformation (Wynne 1989:426). Worse still, crafty locals with such local knowledge will be able to use it to divert state power in ways that are contrary to state goals.

Chiefs, as the administrators of land and depositories of land information before the creation of land boards, were very rich in this local knowledge. Land board members were from these same localities but, like other ordinary citizens, did not have comprehensive information on the history of land parcels beyond their immediate vicinity (Wynne 1989:194). State officials in Botswana early on recognized that land boards needed to know existing land interests to avoid creating conflicting interests by allocating lands that had already been given to others by chiefs. Boards also needed to know the extent and locations of existing land interests so as to document them and settle land disputes.

To reduce these information problems, state officials arranged for chiefs to sit on the new land boards as sources of local knowledge (Botswana 1968b:30; Kalabamu and Morolong 2004:51). Many chiefs exploited this position to continue allocating land, to the chagrin of state and land board officials. Chiefs were removed completely from land boards in 1984 
(Kalabamu and Morolong 2004:51). They can still nominate land overseers, who are 'junior staff within the tribal administration' controlled by chiefs to serve as conduits of local knowledge to land boards (Interviews 20 and 22). These land overseers are supposed to vet applications for land, visit plots and sign off on applications guaranteeing that there are no encumbrances on such parcels before the land boards accept applications (Interview 22). Land overseers are also supposed to travel with land board members during allocation and dispute-resolution trips (Interview 22; Wynne 1989:368-70). Many of them shirk these responsibilities and/or deliberately mislead land boards.

Given the boards' lack of local information, many locals have employed their superior local knowledge relative to land boards to reclaim significant power over land allocation from the land boards. To understand these actors' efforts to resist land board monopolization of the power to allocate land we should reflect briefly on their motivations.

\section{Understanding Differing Motivations}

Because land boards took over land administration powers previously exercised by chiefs, it is understandable that many chiefs and their land overseers resent and resist land boards (Wynne 1989:32, 316-26; Botswana 1968b:30-1). It is not as clear why some clients seek to undermine land boards given what de Soto points out as the beneficial effects for the poor of land documentation (2000). It is supposed to allow land holders to use land as collateral, reduce costly disputes and protect the poor from expropriation. The people I write of here mostly welcome and deliberately seek to document their land parcels. What they object to is the monopoly of the land board over land allocation. They want to determine which parcels the land board should document for them.

Peoples' feelings towards land boards are not monolithic. Comaroff, Werbner and Wynne (Comaroff 1980:108-10; Werbner 2004:80; Wynne 1989:390) provide evidence of how some well-connected individuals embraced and colluded with board members to amass land. Because of the nature of the argument here, I focus on lowly clients lacking connections to board and state officials who seek nonetheless to exercise autonomy over which lands they occupy, use, and/or dispose of. Some of these clients did not recognize the authority of land boards to regulate various transactions that they could once conclude with their neighbors without state interference (Werbner 1980:144-7). Further, as land boards froze the allocation of plots in certain areas and created long waiting lists for land applicants, many people preferred the convenience of getting land when they wanted it. 


\section{Of Floods, Fires, and Other Unfortunate Events}

Faced with an allocation structure they did not always agree with, clients have invented ways of taking land and forcing land boards to legitimize and document these allocations. In Mahalapye, as in other villages in the country, people used three main strategies. They came to the subordinate land board seeking documentation of rights to parcels of land they were already using, claiming variously that: (1) the lands were given to them by chiefs before the land boards had been created and had never been documented; (2) earlier land boards had given them the land but had not issued them with documents; and (3) their documents had been destroyed or lost. Where people claimed they had lost their documents, the main culprits were the floods that occasionally occur in the Mahalapye-Palapye flood plain. Other reasons cited for the loss of documents included children mistakenly lighting fires with them, insects and animals eating certificates and documents getting lost. These demands for documentation dominated the business of the Mahalapye Subordinate Land Board during their allocation exercise in February 2004 (Interviews 24, 25, 31, 32, 33; observation of proceedings at land board meetings).

When faced with such narratives, land board members suspected people of trying to legitimize self-allocated plots. They rightly related the audacity of people to the weak information systems of land boards. The creation of land records was one of the main reasons that the state gave for establishing land boards (Machacha 1986). But record-keeping has been a big weakness of land boards. Because of a lack of trained personnel and logistics, many boards initially granted lands without making proper records or issuing certificates (Kalabamu and Morolong 2004:49). Where they issued certificates, they attached only rough hand-drawn sketches with distances often measured in foot-paces (Interview 53). Many of the land boards I visited did not have functional records past 1990. Where pre-1990 records existed, they were in such a decrepit and disorganized state that routinely resorting to them was a near impossibility for boards, given their resource limitations.

Land board members resist the dissipation of their power to allocate land by people they consider to be ignorant and lowly. They try very hard to stifle clients by asking which chief or land board made the allocation and when it was made. They seek information and signed affidavits from chiefs and neighboring land holders, contact past board officials and staff, and inspect plots to see if boundary posts are newly erected (Interviews 25, 32; observation of land board meetings).

These efforts bear limited fruit because old board members often lack the necessary memory, chiefs and neighbors can be convinced to vouch for 
land claims, and people can learn the names of board members from when they intend to claim they were given land. Yet still I witnessed some of those rare occasions when board members are able to 'prove' self-allocation. At one sitting, a lady came seeking the documentation of land that a certain chief had allegedly allocated to her relative, who was born in 1970. She might not have realized that chiefs lost their power to allocate land when land boards were established in 1970. Further, since the person had been born in 1970, the allocation must have taken place only recently when land boards were well established. She was either lying or trying to legalize an illegal grant by a chief. In another case, a person came to document land in a certain part of the village claiming he had been allocated but not given documents by an earlier land board. Land board members were quick to point out that it was widely known that the area had not been inhabited or used previously in the recent history of the village. Both parties resorted to the time-tested story of missing documents. But the board put their applications aside and informed them that they would be investigated and possibly punished for self-allocation (Interview 24; observation of land board meeting).

In most cases, the land board documented the rights of claimants. Members agreed that while they believed people were trying to legitimize self-allocated plots, they could not prove it because of the lack of records (Interviews 24, 25, 32, 33; observation of land board meetings). Earlier, land boards could refuse documentation based on these suspicions. But the creation of the Land Tribunal in 1997 under the Tribal Land (Establishment of Land Tribunals) Order, Statutory Instrument No. 59 of 1995, changed the incentive structure facing land boards. The Land Tribunal deals specifically with appeals by aggrieved individuals and groups against land board decisions. The Tribunal has held land boards to the strict letter of the law, leading to a string of land board losses to clients that had by 2004 motivated many boards to permanently employ lawyers for legal advice and representation at the Tribunal (Interview 27).

Land board members are no longer willing to risk embarrassing losses at the Tribunal by rejecting applications for documentation based on mere suspicions. A subordinate land board member stated that 'Self allocation is a big problem here. We cannot trace old records, but we cannot risk losing at the Land Tribunal by making a decision based on suspicion without evidence.' He pointed out that 'people in Xhosa I and Tshikinyega always claim floods washed away their land certificates, but when we ask them their marriage licenses, death certificates or party membership cards are never destroyed by the floods and fire' (Interview 25). Another board member pointed out that 'Most of the time we know they are lying. We threaten them with the 
10.000 pula fine and one year in jail, but we have no way of proving that they are lying. Our lack of records forces us to be lenient. We just regularize the claims that they make' (Interview 32). An even more despondent board member complained that 'People have greed over land. Most of their certificates were not swept by flood. People have cattle brand certificates, birth certificates except their land certificates. The DC [district commissioner] is not complaining about reregistering birth and marriage certificates' (Interview 33). The exasperated tone and accusations of duplicity of these board members reminds one of the frustrations that led one Japanese landlord to wonder: 'Does anyone lie as much as a peasant?' (Scott 1990:18).

Are people really reappropriating the power to allocate land or are these just the rants of paranoid board members? The fact that people who commit this 'illegality' have little incentive to admit it to those outside their in-group makes clear-cut evidence of the stratagem of reappropriation difficult to come by. Yet still there is evidence of self-allocation and the ongoing struggles over the power to allocate land between land boards and various societal actors. In response to surveys by Kalabamu and Morolong in Old Mogoditshane and New Mogoditshane close to the capital Gaborone after 2001, 5 and 4 per cent respectively of participants admitted to self-allocation (Kalabamu and Morolong 2004:148). Given the widespread knowledge of extensive self-allocation, particularly in those peri-urban areas, Kalabamu and Morolong rightly put the low figures down to the 'fear of admitting wrongdoing in a country where the culture detests disobedience to authority or to fear of retribution' (Kalabamu and Morolong 2004:148) (which includes the occasional and recent demolition of illegal houses by the state).

The two cases highlighted above in which land board members through rigorous questioning were able to uncover illegal allocations are only two of what land board members claim are many cases of self allocation that they were able to expose.

We see further evidence of these hostile efforts by Batswana to retake land allocation power from land boards in the wily and illegal conversion of farms into residential plots around the country. In Borotsi ward in Bobonong, many land users sensed the gradual extension of Bobonong village in their direction and anticipated rising land values and the repossession of their farms for conversion into residential plots by the land board. They subdivided their farms, built houses, and dished out land to others as 'gifts' from the late 1990s. When they were confronted by the Bobonong Subordinate Land Board, they claimed among other things that the new houses were just homesteads on their farms, that the builders were family members and that they were not making any efforts to change the land from agricultural to 
residential use. More interestingly, they claimed that in any case Borotsi was outside the limits of Bobonong and therefore the Bobonong Subordinate Land Board had no jurisdiction over their farms. They said they would talk to the land board and register their holdings once the village reached them! (Interview 35). Exasperated board members have had to look on as people convert their farms into residential property under the guise of allowing 'family members' to build homesteads to enhance their proximity to farms.

The case of masoko in Bobirwa Sub-District provides more evidence of success by societal members in their efforts to prise valuable land allocation power out of the hands of land boards. Masoko are shallow wells dug in dry river beds from which cattle ranchers can use machines to pump water into troughs. These are supposed to be temporary spring wells that get covered by sand when rivers begin to flow. People do not need land board approval to dig these wells. But they do need such approval to sink permanent boreholes. The Tribal Land Act (1968) does not distinguish between masoko as opposed to boreholes. Cunning cattle ranchers have seized on this loophole to engage in what the land board sees as self-allocation. They use explosives and heavy earth-moving equipment to sink very deep permanent wells close to river beds. When the land board accuses them of self-allocation and sinking boreholes without approval, ranchers retort that these are mere masoko, that the land board has no right to allocate land in river beds and that the law allows for masoko. An irate board staff noted that 'when we approach them they claim the law allows them to dig masoko. If we press them, they hire lawyers who ask us to produce a legal definition of masoko' (Interview 36).

Reflecting on the difficulty states face in imposing their designs on peasants in Tanzania, Hyden noted that 'In this situation, it is understandable if the development equation is often reduced to a zero-sum game. The African peasant is hardly a hero in the light of current development thinking, but by using his deceptive skills he has often defeated the authorities' (Hyden 1980:231). But do these successful efforts at reclaiming the power to allocate land also empower land boards and central state officials? I argue below that what seems like a zero-sum game and thorough defeat of the state on the surface in actual fact also significantly empowers land boards and central state officials.

\section{Empowering Land Boards and the State}

By tricking land boards into legitimizing their interests, people bring themselves into the purview of land boards and contribute to updating the land information system of the land boards. Better land information systems are critical to the ability of land boards to allocate land and resolve land disputes in informed ways. Further, better information systems limit the extent to 
which societal members can chip away at the monopoly of land boards over the power to allocate land. Better information systems also enable central state officials to tax, plan, and provide various social services.

\section{The Nature and Role of Land Information Systems}

State authorities need accurate information systems to enable them achieve their ends of social transformation (Scott 1998:183). Land information systems create and keep information on the location and dimensions of various parcels of land, interests in these parcels and various transactions concerning land parcels. These systems could take the form of chiefs and elders that act as repositories of information on land parcels or land title and deeds registries. Maps indicating the dimensions, locations, interests, and transactions in land parcels represent easily visualized examples of such land information systems.

My argument incorporates Black's (1997:22) view that maps have been key instruments in the furtherance of the dominating and transformative projects of rulers. Of particular interest here is the role of land information systems as the eyes that direct the use of state power to achieve various ends including 'vaccinat[ing] a population, ... tax[ing] people and their property, ... conscript[ing] soldiers' (Scott 1998:183), generating markets and facilitating land transactions (de Soto 2000:ch. 3). Often, this goal of generating market activity masks the redistributive uses to which these information systems are put. The creation of maps and registration of various land instruments do not just capture interests as they are on the ground. They also create new interests and eliminate others (Ngugi 2004:476). As in the US, colonial South Africa and Zimbabwe these systems were deployed by the powerful to facilitate, legitimize, and calcify land seizures from the less powerful. In other cases this redistributive result is a non-deliberate effect. New land documentation systems allow the wily to register instruments for lands in which they have no interests at the expense of less knowledgeable and influential owners (Scott 1998:48).

This utility of land information systems is matched by the difficulty of amassing such information systems. It is a costly exercise, requiring expertise in surveying, recording and documentation, and a presence of the state across its territory. Land boards earlier on struggled badly with the tasks of documenting and keeping records on land interests because they lacked trained staff and equipment (Machacha 1986; Kalabamu and Morolong 2004:49). Land information systems are also highly susceptible to what Thelen and Streeck call 'drift', which occurs when the failure to 'recalibrate and renegotiate' institutions in line with changing social realities over time results in their demise (Thelen and Streeck 2005: 24). Land transactions of various 
sorts are constantly going on, so in order for a land information system to be accurate, it has to be constantly updated to reflect these changes. Not updating these records is tantamount to actively distorting them.

I do not intend to claim that state officials always intend the information systems they advertise to truly reflect relevant realities. The point I am making here is that state authorities need accurate information systems to enable them achieve their ends, including the end of deliberately putting out false information, as they often chose to do. Often, authorities put out information systems that reflect their aspirations - how they wish or intend realities to be (Black 1997:18). In 1970 the Fundação Nacional do Índio (FUNAI) in Brazil issued land titles to cattle ranchers for 'uninhabited' land in the Guapore valley in the Amazon, which turned out to be the 'homeland of the Namibiquara' people. Given the zealous advocacy of the head of FUNAI to 'develop' Indian reserves, this silence or non-recognition of the existence of the Namibiquara has to be interpreted as strategic blindness (Hecht and Cockburn 1989:138). FUNAI needed accurate information to enable it to declare as waste or uninhabited landed properties of the Namibiquara instead of those of powerful loggers and mineral prospectors. The colonial government in Kenya similarly declared areas of the country, which it wanted to expropriate from blacks for exclusive white use, as 'waste land of which it had the right and duty to make disposal in the way which it deemed best for the country at large' (Kenya 1933:12) This declaration was preceded by careful and extensive studies on the boundaries and holdings of various groups (Kenya 1933) to enable it declare as waste land the holdings of the Masai and other African groups instead of the holdings of powerful European settlers like Lord Delamere.

\section{Coming into the Purview of the State}

By tricking boards into legitimizing their self-allocated plots, people contribute to the land information systems of the state. They emerge from the shadows into the purview of the state, eliminating the information barricades that hide the dominated from elites and so guarantee them some freedom from interference (Scott 1990:132). Speaking of this breaking of information barricades in the West in highly positive terms, de Soto notes that 'Once inside a formal property system, owners lost their anonymity. By becoming inextricably linked to real estate and businesses that could be easily identified and located, people forfeited the ability to lose themselves in the masses' (2000:55).

While de Soto is right in pointing out one of the effects of title registries, it is not clear that clients always valorize this loss of anonymity, as Scott (1990:133) shows in reference to strenuous efforts by Southeast Asian 
peasants to escape the gaze of inquisitive colonial officials. Similarly, in Kenya state efforts at registering land in Coast Province in the early 1960s met stubborn resistance by some land holders. For instance, when approached by state agents to agree to registration efforts, the elders of Rabai, Kilifi District curtly told the Government Agent that 'wa-Rabai know their shamba [farm] boundaries and ... they do not feel like the government should put them on the ground' (Kenya National Archives) They (rightly) suspected that knowing and demarcating their boundaries was a first step in the eventual expropriation of their lands. These efforts to escape the gaze of the more powerful are not limited to the poor and powerless. When the naturalist von Humboldt as the agent of the Spanish king went to the Amazon to collect cartographic data and specimens at the end of the eighteenth century, Brazilian officials regarded Humboldt and other scientists and cartographers from Europe and the US with great suspicion. Speaking of the assiduous efforts of Humboldt, one Brazilian official remarked that 'I never saw anyone measure so carefully land that was not his' (Hecht and Cockburn 1989:7). When one notes the designs of other nations on the Amazon and continuing talk about the internationalization of the forest, this suspicion was warranted.

Given the potential benefits of land documentation to the poor and powerless that are touted by de Soto (2000), such occasional resistance of land documentation by land users is puzzling. But this is so only because de Soto completely neglects the almost inevitable negative distributional consequences of titling and other documentation efforts for clients that I point out above. Fear of these distributional consequences and the use of land documentation efforts to aid taxation ensure that the poor and powerless are not always eager to embrace efforts at documenting land interests (Scott 1998:48).

Against this background we can see why the willing emergence of Batswana land users from the shadows into the land information system of the state constitutes a boon for state efforts at compiling and updating land information systems. Batswana were providing the state with valuable information with which it could perform various tasks, and without which it is bound to fail in its transformative projects.

\section{Enhancing the Power of Land Boards and of the State}

The better land board records that result from people fooling land boards into legitimizing their self-allocated plots benefit land boards by enhancing their power to engage in informed dispute resolution and land allocation. Over time it also limits the extent to which clients and land overseers can cunningly rob them of the power to allocate land. Better records help the 
state by providing it with information that they can use to tax, police, and plan and implement various social projects better (Interview 9).

It is important to separate discussions of how land boards and central state officials are empowered because we should not assume that what empowers land boards empowers central state officials and vice versa. Principal-agent theory and the literature on rent-seeking would lead us to expect that board members might have preferences different from those of their central state principals. Board members might even prefer to hide their records from central state bureaucrats to increase their discretion in land allocation and conflict resolution.

Regardless of how board members decide to use their records, better records empower land boards by boosting their ability to monopolize the power to allocate land and to engage in land allocation and dispute resolution in more informed ways. Ignorance of existing land interests has fundamentally undermined the ability of land boards to make informed allocation decisions and led them into creating conflicting interests (Wynne 1989:431-7; Interviews $25,32)$. There are many people in Botswana who own but do not develop or mark plots. Sometimes, others not knowing of the interests in these plots apply to the land board for the same land parcels. Land boards then allocate these plots thereby creating conflicting interests through double allocation (Interviews 14, 21). The emergence of the old owner causes conflict and makes boards look inept and ridiculous in the eyes of clients and central state officials. As more people bring their land interests to the attention of the land board through various means, the board gains better knowledge of existing interests and so is able to reduce the extent to which it engages in double allocation. Also, once a person brings their interests to the land board, it makes it more difficult for them to fool the board later by claiming a more extensive parcel.

Bringing their existing land interests to the attention of the land board through various stratagems also boosts the ability of boards to resolve disputes. To make informed decisions when they are faced with disputes over boundaries, encroachment and conflicting interests, they need to know the location and dimensions of interests as well as ongoing transactions. As people bring their claims to the attention of the land board, enabling the board to better its land information system, the boards will find it easier to resolve these disputes.

Importantly, land board members are acutely aware of the need to expand and upgrade their records. They have employed radio announcements and kgotla meetings to encourage people to documents their interests (Interviews $27,33)$. This is partly a deliberate effort to take advantage of much improved 
land board information-gathering and storing capabilities, which include bettertrained staff, GPS equipment and the gradual introduction of computerized information management systems. The manipulation of knowledge by clients to reappropriate the power to allocate land from the land boards gives people a non-illegal means through which they can fulfill the wishes of - and bring their interests to the attention of - the land boards and the state.

The empowering effects of the hostile actions of clients go beyond land boards to other state agencies. The information systems that people contribute to through their stratagems, aid the Department of Taxes to assess and collect rental income, capital gains and inheritance taxes. The state also uses this information to monitor and police its population. Further, these land board records contribute to demographic information that guides urban and rural planning and the delivery of services such as electricity and sewage.

The Batswana state is aware of its need for and has made efforts to create such information systems. Because of its dissatisfaction with existing land records the Government of Botswana contracted Data Infotech of India to create a State Land Information Management System (SLIMS) and a Tribal Land Information Management System (TLIMS). By 2004 SLIMS was being piloted in Gaborone and Lobatse. These are web-enabled, up-todate, integrated land data banks that will contain information on every parcel of land in Botswana and will be available to various state agencies. According to one of the senior officials in charge of SLIMS, the systems are supposed to achieve a variety of functions. These include helping agencies to allocate and document land and assisting district councils to administer building material loans, collect service levies and taxes. They are also supposed to help the Department of Lands collect transfer duties and revenues on properties leased out by the state. Further, the Estate and Valuation Division will use these systems in their valuation and acquisition of land (Interview 9).

There is clear evidence of the link between land information systems and the expansion of public infrastructure in Botswana. During the February 2004 allocation exercise of the Mahalapye Subordinate Land Boards, applications for the documentation of existing land interests surpassed all other demands made by clients. Board members explained to me that the surge was in response to the new rules of two state agencies. The Botswana Power Corporation and the Department of Water Affairs now required applicants to show proof of land rights to be connected to the electricity and water grids. An official at the Department of Water Affairs explained that the requirements were to avoid situations where the department brought pipes to what was supposed to be the land of an applicant only for another person to tell them to desist from causing a nuisance on their property. The 
department also wanted to avoid problems with collecting rates from nonpaying applicants who turned out not to be the owners of the properties (Interview 28). Electrification exercises in Tsetsebye and Semolale in Bobirwa similarly drove many people to register their land parcels with the Bobonong Subordinate Land Board (Interview 34). Hernando de Soto rightly points out the usefulness of title registries in reducing the 'risk of theft of [utility] services' and the costs of 'bill collection among people hard to locate'. He goes on to ask: 'On what other basis could they [utility providers] identify subscribers, create utility subscription contracts, establish service connections, and ensure access to parcels and buildings?' (de Soto 2000:59).

The Department of Water Affairs imposed similar requirements to facilitate the construction of a pipe-borne sewage system in Mahalapye under its Major Villages Sanitation Project. The project, which started in 2003, was supposed to lay $46.6 \mathrm{~km}$ of major pipes and $286.5 \mathrm{~km}$ of tertiary pipes in Mahalapye. The department had to take over and compensate owners of properties under which some pipes were going to pass. But it had problems identifying which people to negotiate with and pay compensation to. Unsurprisingly, there were people eager to receive compensation for properties that they did not own. To forestall the confusion and loss of revenue and time, the department asked all property owners to bring documents proving their land interests from the land boards. It then intended to rely on the records of the land boards to distribute compensation to those affected by the project (Interview 29).

\section{The Contributions of Resistance to Dominating Structures}

This study raises the broader theoretical issue of the contribution of subversion and resistance to the creation of dominant structures. Why, out of many developing states facing hostile social forces, do some become stronger and go on to undertake positive social transformation while others become weaker and slide further towards the path of negative social transformation? Exploring this question brings to the fore the role of the goals and capacity of social actors, the goals and character of various state officials and the nature of the area/subject of contention in explaining the impact of successful social resistance on states (Hirschman 1970; Dowding et al. 2000; Jackson 1990).

Such research presents challenges on different levels. Because its dependent variable is counter-intuitive and not widely recognized detailed analysis of multiple societal and state segments over time has to be done to establish the very fact of variation that needs to be explained. Observation from a distance will yield what meets the distant gaze in such situations as in the case of Botswana, where observers only notice the subversion and defeat of the state's project of rationalizing rural land allocation. 
The investigation of subversion and illegality against state projects makes this subject matter highly sensitive. Given the severity of possible punishments, it is understandable that people take care to hide their activities. Unearthing these hidden activities calls for the adoption of methods that look below surface phenomena to what Scott has described as 'hidden transcripts', those acts of resistance that the dominated deliberately hide from public view (1990). This requires gaining the trust of actors and developing interpretive schemes that allow one to grasp the deeper import of what on the surface appear to be mundane acts with obvious meanings. Participation in the activities of and multiple semi-structured in-depth interviews with research subjects are invaluable for gaining their trust and understanding their wider worldview, which provide interpretive schemes within which actors' actions can be understood. Archival research can provide valuable historical information against which events can be read and interpreted.

\section{Conclusion}

Hostile confrontations in which clients have been able to reappropriate some powers to allocate land from land boards have also ended up benefiting the land boards and the state. This account exposes the extent to which much of the state-in-society literature is underpinned by inattention to the possibility of unintended consequences. The state-in-society literature improves on the earlier view that portrayed all state-society interactions as zero-sum. But its allowance for mutually empowering interactions is built on a view of such instances of mutual empowerment as the effects of deliberate collaboration geared towards the achievement of mutual goals (Kohli and Shue 1994:321; Migdal 1994:24-5; Schneider 1998:49). My analysis demonstrates the need to infuse this literature with a consideration for unintended consequences. State and societal forces might set out to disempower each other. The actions that are meant to disempower might, however, produce the unintended consequence of empowerment. Thus, clients who resent the monopolization of land allocation powers by land boards set out to and have succeeded in taking back some of that power from land boards. But this successful subversion has produced the unintended consequence of strengthening the boards and the state by improving records that they can used to transform society.

This counter-intuitive dynamic hinges on a serious consideration of what Kohli and Shue (1994:294), among others, point out as the multi-segmented and recursive character of state-society interactions. A segment of society might inflict a blow on a segment of the state. But this blow might strengthen another segment of the state in its relations with the same or another segment 
of society. In Botswana popular stratagems that seem to undermine the power of the land board to allocate land also improve the state's land information system and so empower the Department of Water Affairs to perform its transformative and administrative tasks. Further, successful efforts by one segment of society to cripple a state agency in an iteration of their interactions might better prepare the same segment of the state for its later interactions with that same facet of society. For instance, a certain Thebogo might fool the land board into legitimizing her land claim and so take back some power over the allocation of land. But once the board legitimizes her claim by documenting it, this provides the board with ammunition that it can use to detect and punish later efforts by that Thebogo to fool the board into documenting further extensions of her boundaries.

\section{References}

Anderson, P., 1979, Lineages of the Absolutist State, London: Verso.

Arhin, K., 1985, Traditional Rule in Ghana: Past and Present, Accra: Sedco.

Black, J., 1997, Maps and Politics, Chicago: University of Chicago Press.

Botswana, 1968a, National Development Plan, 1968-73, Gaborone: Government Printer.

Botswana, 1968b, Official Report of the Proceedings of the Thirteenth Meeting of the House of Chief Sittings from $5^{\text {th }}-7^{\text {th }}$ August 1968, Gaborone: Government Printer.

Bratton, M., 1994, 'Peasant-State Relations in Postcolonial Africa: Patterns of Engagement and Disengagement', in J. Migdal, A. Kohli and V. Shue, eds, State Power and Social Forces, New York: Cambridge University Press.

Comaroff, J., 1980, 'Class and Culture in a Peasant Economy: The Transformation of Land Tenure in Barolong', Journal of African Law 24 (Spring)

De Soto, H., 2000, The Mystery of Capital: Why Capitalism Triumphs in the West and Fails Everywhere Else, London: Bantam.

Dowding, K. et al., 2000, 'Exit, Voice and Loyalty: Analytic and Empirical Developments', European Journal of Political Research 37(4).

Evans, P., 1995, Embedded Autonomy: States and Industrial Transformation, Princeton: Princeton University Press.

Hayek, F., 1945, 'The Use of Knowledge in Society', American Economic Review 35 (September)

Hecht S. and Cockburn, A., 1989, The Fate of the Forest: Developers, Destroyers and the Defenders of the Amazon, London: Verso.

Herbst, J., 2000, States and Power in Africa: Comparative Lessons in Authority and Control, Princeton: Princeton University Press.

Hirschman, A., 1970, Exit, Voice and Loyalty: Responses to Decline in Firms, Organizations and States, Cambridge, MA: Harvard University Press. 
Hobsbawm, E., 1973, 'Peasants and Politics', Journal of Peasant Studies 1 (October).

Hyden, G., 1980, Beyond Ujamaa in Tanzania, London: Heinemann.

Hyden, G., 1983, No Shortcuts to Progress, Berkeley: University of California Press.

Jackson, R., 1990, Quasi-states: Sovereignty, International Relations and the Third World, New York: Cambridge University Press.

Kalabamu, F. and Morolong, S., 2004, Informal Land Delivery Processes and Access to Land for the Poor in Greater Gaborone, Botswana, Birmingham: International Development Department, School of Public Policy, University of Birmingham.

Kang, D., 2002, Crony Capitalism: Corruption and Development in South Korea and the Philippines, New York: Cambridge University Press.

Kenya, 1933, Report of the Kenya Land Commission, Nairobi: Government Printer.

Kohli, A. and Shue, V., 1994, 'Contention and Accommodation in the Third World', in J. Migdal, A. Kohli and V. Shue, eds, State Power and Social Forces, New York: Cambridge University Press.

Machacha, B., 1986, 'Botswana’s Land Tenure: Institutional Reform and Policy Formulation', in J. W. Arntzen, W. L. D. Ngcongco, and S. D. Turner, eds., Land Policy and Agriculture in Eastern and Southern Africa: Selected Papers presented at a workshop held in Gaborone, Botswana, 14-19 February, 1982, Tokyo: United Nations University.

Mathuba, B., (n.d.), 'Land Administration in Botswana', paper prepared for the National Conference on Land Reform, Namibia.

Migdal, J., (1988,) Strong Societies and Weak States, Princeton: Princeton University Press.

Migdal, J., 1994, 'The State in Society: An Approach to Struggles for Domination', in J. Migdal, A. Kohli and V. Shue, eds, State Power and Social Forces, New York: Cambridge University Press.

Molosiwa, R., 1999, Botswana: An Official Handbook, 5th edn, Gaborone: Publicity Unit.

Ngugi, J., 2004, 'Re-examining the Role of Private Property in Market Democracies: Problematic Ideological Issues Raised by Land Registration’, Michigan Journal of International Law 25 (Winter).

Nyamnjoh, F., 2007, “Ever Diminishing Circles”: The Paradoxes of Belonging in Botswana’, in M. de la Cadena and O. Starn, eds, Indigenous Experience Today, New York: Berg.

Picard, L., 1985, Politics and Rural Development in Southern Africa: The Evolution of Modern Botswana, London: Rex Collings.

Proctor, J. H., 1968, 'The House of Chiefs and the Political Development of Botswana', Journal of Modern African Studies 6 (May).

Samatar, A., 1999, An African Miracle: State and Class Leadership and Colonial Legacy in Botswana Development, Portsmouth, NH: Heinemann. 
Schneider, B. R., 1998, 'Elusive Synergy: Business-Government Relations and Development', Comparative Politics 31 (October).

Scott, J., 1985, Weapons of the Weak: Everyday Forms of Peasant Resistance, New Haven, CT: Yale University Press.

Scott. J., 1990, Domination and the Arts of Resistance: Hidden Transcripts, New Haven, CT: Yale University Press.

Scott, J., 1998, Seeing Like a State: How Certain Schemes to Improve the Human Condition Have Failed, New Haven, CT: Yale University Press.

Spruyt, H., 1994, The Sovereign State and its Competitors, Princeton: Princeton University Press.

Thapelo, W., 1997, The Traditional Tswana Kgotla: Let Us Know and Preserve our National Heritage Together, Gaborone: Department of Printing and Publishing Services.

Thelen, K. and Streeck, W., 2005, 'Introduction', in W. Streeck and K. Thelen, eds, Beyond Continuity: Institutional Change in Advanced Political Economies, New York: Oxford University Press.

Tilly, C., 1990, Capital, Coercion and European States, Cambridge, MA: Blackwell. Weber, M., 1946, 'Politics as a Vocation', in H.H. Gerth and C. Wright Mills, eds, From Max Weber: Essays in Sociology, New York: Oxford University Press.

Werbner, R., 1980, 'The Quasi-judicial and the Experience of the Absurd: Remaking Land Law in North-Eastern Botswana', Journal of African Law 24 (Spring).

Werbner, R., 2004, Reasonable Radicals and Citizenship in Botswana: The Public Anthropology of Kalanga Elites, Bloomington: Indiana University Press.

Wynne, S., 1989, 'The Land Boards of Botswana: A Problem in Institutional Design', unpublished Ph.D. dissertation, University of Indiana.

\section{Interviews}

Interview (9) with a member of the State Lands Information Management System (SLIMS) at the Department of Lands in Gaborone, 21 January 2004.

Interview (11) with the Permanent Secretary, Ministry of Lands and Housing in Gaborone, 22 January 2004.

Interview (14) with a technical officer of a subordinate land board, 27 January 2004.

Interview (20) with a subordinate land board clerk, 4 February 2004.

Interview (21) with a technical officer in a subordinate land board, 4 February 2004.

Interview (22) with a land board official, 11 February 2004.

Interview (24) with a land board staff member, 12 February 2004.

Interview (25) with a land board member, 13 February 2004.

Interview (27) with an administrative staff member at a main land board, 16 February 2004. 
Interview (28) with a technical officer, Department of Water Affairs, Mahalapye, 28 February 2004.

Interview (29) with an assistant resident engineer at Guaff Liebenberg and Stander International, Mahalapye, 17 February 2004.

Interview (31) with a land board staff member, 18 February 2004.

Interview (32) with a land board member, 20 February 2004.

Interview (33) with a land board member, 21 February 2004.

Interview (34) with a subordinate land board clerk, 23 February 2004.

Interview (35) with a staff member at a subordinate land board, 23 February 2004.

Interview (36) with a deputy land board clerk, 23 February 2004.

Interview (53) with a deputy Subordinate land board clerk, 17 March 2004.

\section{Archival source}

Kenya National Archives CA/10/120, Letter from Assistant Regional Government Agent, Kaloleni to Regional Government Agent, Kilifi, 11 June 1964. 